\title{
WestVirginiaUniversity
}

THE RESEARCH REPOSITORY @ WVU

West Virginia Agricultural and Forestry Experiment

Davis College of Agriculture, Natural Resources

Station Bulletins

And Design

$1-1-1952$

\section{Nutritional survey of West Virginia University students}

\author{
Faith Wolfe Chalmers \\ John Joseph Lawless
}

Sam Stregevsky

Follow this and additional works at: https://researchrepository.wvu.edu/ wv_agricultural_and_forestry_experiment_station_bulletins

\section{Digital Commons Citation}

Chalmers, Faith Wolfe; Lawless, John Joseph; and Stregevsky, Sam, "Nutritional survey of West Virginia University students" (1952). West Virginia Agricultural and Forestry Experiment Station Bulletins. 352.

https://researchrepository.wvu.edu/wv_agricultural_and_forestry_experiment_station_bulletins/352 @ WVU. It has been accepted for inclusion in West Virginia Agricultural and Forestry Experiment Station Bulletins by an authorized administrator of The Research Repository @WVU. For more information, please contact ian.harmon@mail.wvu.edu. 


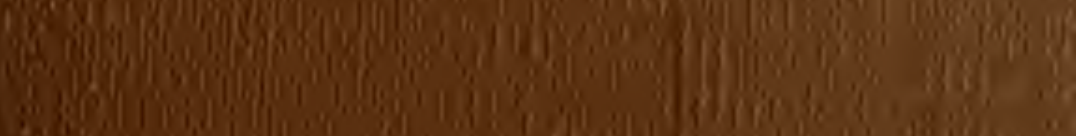

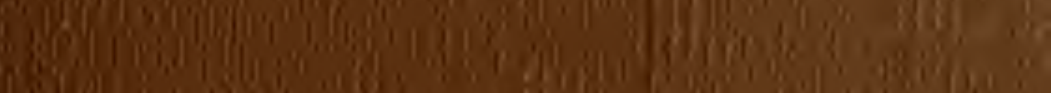

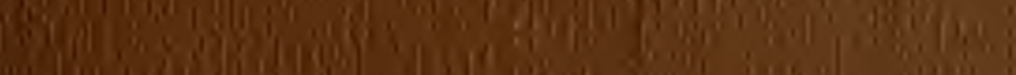

(I)

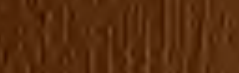

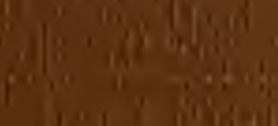

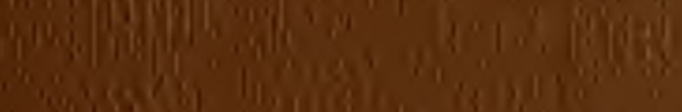

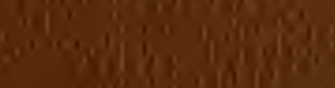

II) 19

14

$\left.3\right|^{1}+\frac{1}{8}, 1$

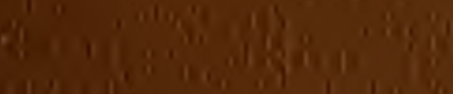

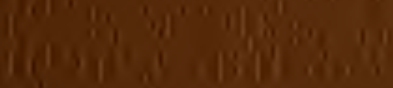

13

yis

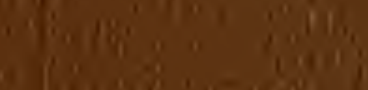

$\lim _{11}^{11} 1$

${ }_{111}$

ivin

IX)

It)

$x^{2}+x^{2}+1$

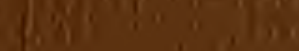

Ti

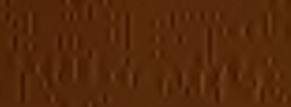

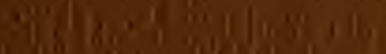

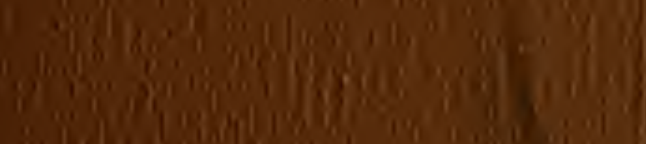

(I)

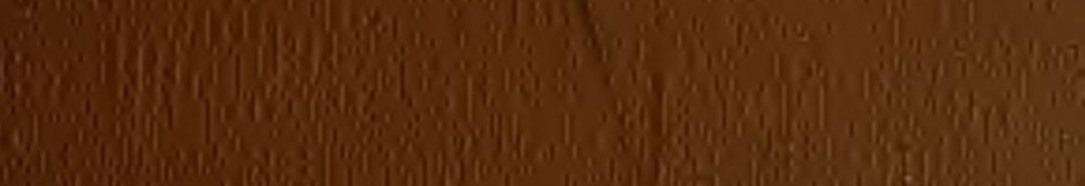
I :

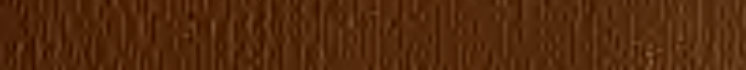





\section{Nutritional Survey}

\section{of West Virginia University Students}

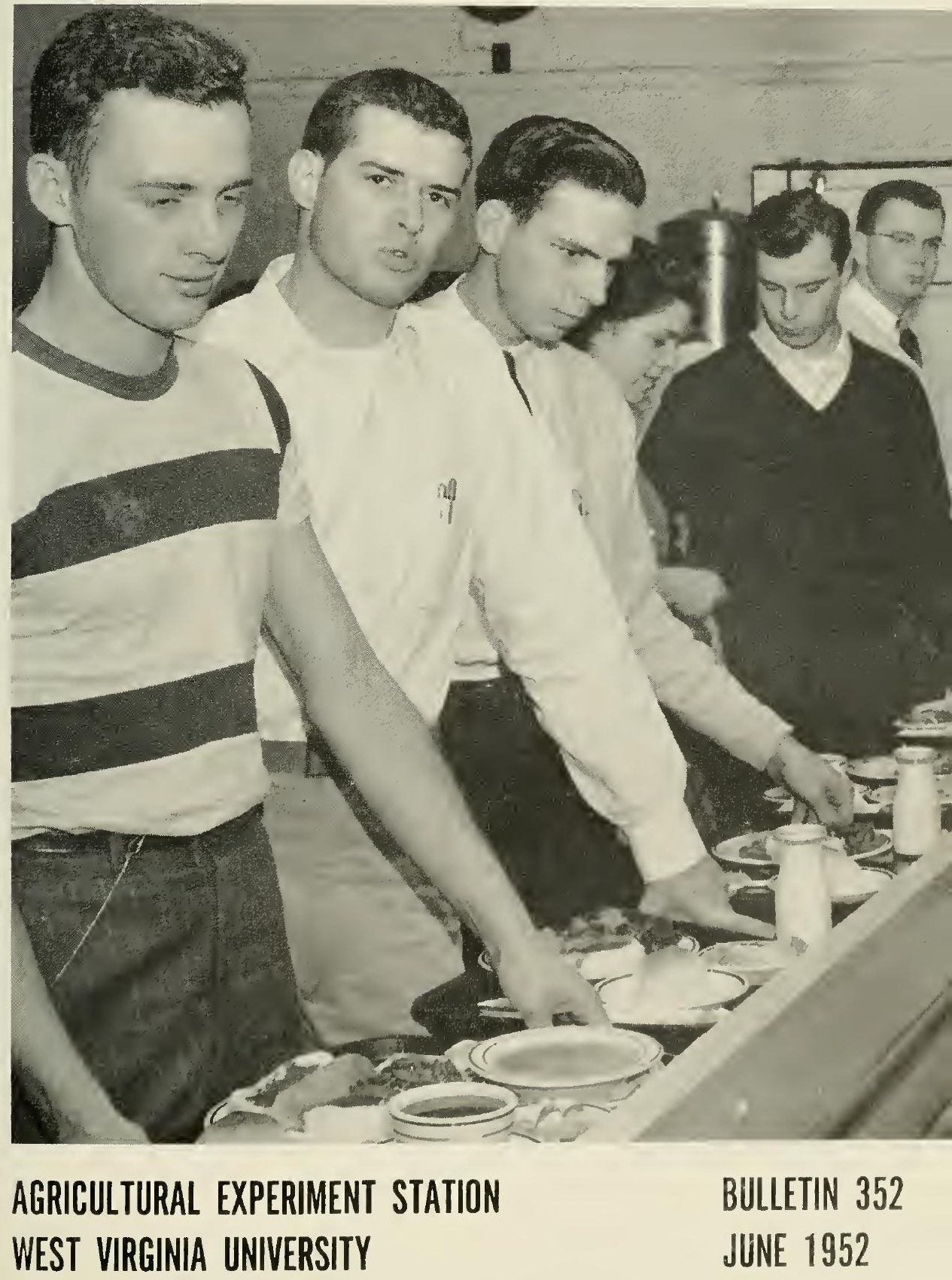


FAITH WOLFE CHALMERS is Research Assistant in Human Nutrition of the Division of Home Economics, College of Agriculture, Forestry, and Home Economics.

DR. JOHN JOSEPH LAWLESS is Director of the University Health Service and Associate Professor of Medicine in the School of Medicine.

SAM STREGEVSKY was formerly Assistant Agricultural Biochemist of the West Virginia University Agricultural Experiment Station.

Other workers contributing to this bulletin were Ira Joseph Price, Jr. and Marian Brooks Cornell.

This bulletin is a progress report on nutritional status studies in West Virginia. The research is a part of the Northeast Regional Nutritional Status project being done cooperatively by the agricultural experiment stations of Maine, Massachusetts, New Jersey, New York, Rhode Island, and West Virginia under the Research and Marketing Act of 1946.

WEST VIRGINiA UNIVERSITY

Agrigultural Experinient Station

College of Agriculture, Forestry, and Home Economics

H. R. VARNey, DiREctor 


\section{Nutritional Survey}

\section{of West Virginia University Students}

\section{Summary and Conclusions}

A survey of the nutritional status of college students was made at West Virginia University during the fall of 1948 and continuing through the winter of 1950 as part of a cooperative study of nutritional status in the Northeast Region. Dietary studies, microchemical blood studies, and medical examinations were used to determine nutritional status.

Physical examinations of 335 college students revealed few signs of deficiencies generally related to poor diets. However, these signs are important because they may be indicative of inadequate nutrition over long periods of time.

In blood samples obtained from over 1,000 students, it was found that, on the average, men had lower blood concentrations of vitamin $\mathrm{C}$ and carotene than women. On the other hand, women had lower blood concentrations of vitamin A and hemoglobin. Approximately 20 per cent of the students had blood levels that were rated "poor" for one or more of the following nutrients: carotene, vitamin A, and vitamin C.

Information concerning dietary intake and food habits as obtained from 535 seven-day diet records indicates there is much room for improvement in the diets of West Virginia University students. The diets were lower in calcium, phosphorus, vitamin $\mathrm{A}$, and vitamin $\mathrm{C}$ in comparison with the Recommended Daily Allowances of the National Research Council. The nutritive quality of these diets could be made to meet or to exceed the standlards of the National Research Council with only a few changes in present food consmmption. 


\section{Introduction}

Are West Virginians Well Fed?

To be well fed means more than just to appease hunger. It means eating every day all of the foods needed for health and vitality. Compared with other countries, the United States is rich in food. Are we using our resources to the best advantage?

Studies made in different parts of the country indicate that many people are living on diets inadequate for good nutrition. This does not mean that all of these people are going hungry. Nor does it mean that many of them are suffering from pellagra, beriberi, scurvy, or any other well-defined nutritional disease. Most nutritional deficiencies that exist in America today are of a mild or chronic nature. Such types may not actually keep a person in bed, but they may cut down on his efficiency, reduce his natural resistance to infection, and destroy his general sense of well-being. Such unrecognized and untreated deficiencies may be keeping many people from living up to their potential achievements in life.

Establishing and maintaining good food habits within a nation is very difficult. Diet patterns of different groups of people, as well as individuals, will differ widely, due to varying economic, social, and environmental factors. In order to obtain specific information about the food habits and nutritional status of groups within a given area, periodic mutrition surveys of representative population groups must be made. This type of information is needed as the basis for a sound educational program in nutrition.

In 1947 a cooperative study of the methods of assessing nutritional status of various population groups was undertaken by six agricultural experiment stations in the Northeast Region of the United States. Stations cooperating were Maine, Massachusetts, New Jersey, New York, Rhode Island, and West Virginia. A research team, which usually included a nutritionist, a biochemist, and a physician, was organized within each state participating in the study.

The work done in each state consisted of: dietary studies to determine average daily intakes of calories, proteins, vitamins, and minerals: microchemical blood studies to determine blood levels of hemoglobin, vitamin $A$, carotene, and vitamin $\mathrm{C}$; and medical examinations to detect any physical signs of nutritional deficiencies. Methods used in obtaining this information have been described previously. ${ }^{I}$ Maine and New

1Northeast Regional Publication No. 5; Cooperative Nutritional Status Studies in the Northeast Region; I. Techniques. Memoir No. 307, Cornell Univ. Agr. Expt. Sta., Ithaca, N. Y., 1951. 
York have studied junior high students, and Rhode Island has studied high school boys and girls. Massachusetts has studied the nutritional status of pregnant women. Rhode Island and West Virginia have worked with college students, and New Jersey has studied the nutrition of industrial workers.

At West Virginia surveys are being conducted cooperatively by the Department of Agricultural Biochemistry, the Division of Home Economics, and the University Health Service. The purpose of this study is to determine the nutritional status of various population groups and to find ways of correcting any nutritional deficiencies that may exist.

A survey of the nutritional status of college students was begun in the fall of 1948 and was continued through the winter of 1950. During this period 1,362 college students, 841 men and 521 women, were studied by one or more of the methods described above.

\section{Physical Examinations}

On entering college, each student at West Virginia University receives a complete medical examination. In addition, 335 of the students cooperating in this nutrition survey were given special physical examinations to detect possible signs of nutritional deficiencies. OI these 335 students, 210 were men and 125 were women. All were examined by the same physician. He checked for the presence of certain conditions that are usually associated with poor nutrition. Results of these examinations are given in Table 1.

Few signs of poor nutrition were found among the students. Those signs noted were generally of a very mild type. For example, only three persons showed inflammation of the eyelids (blephavitis). Two persons showed inflammation of the conjunctiva, the mucous membrane which lines the inner surface of the eyelids. Thirty-five students showed increased vascularity of the conjunctiva. Oily plugs in the skin around the nose (nasolabial seborrliea) were seen in 19 cases. Mild cases of pimples (acne) were noted in 12 persons. Six of the men had rough, dry goose-pimply skin (folliculosis) or dry, scaly skin (xerosis). All of these skin conditions, however, occurred only in very mild or moderate forms.

Ten of the students examined had reddened, peeling lips (cheilosis). Thirty-four nen and six women, I2 per cent of all students examined, showed mild or moderate inflammations ol the gums (gingivitis). Swelling, changes in color, fissuring, or changes in the papillac of the tongue were observed in only 12 cases. Slight enlargements of the thyroid gland 
Table 1. Incidence of Physical Signs Possibly Related to Nutritional Deficiencies in 355 West Virginia University Students*

\begin{tabular}{|c|c|c|c|c|c|}
\hline \multirow{2}{*}{ PHYSICAL SIGNS } & \multicolumn{2}{|c|}{ MEN } & \multicolumn{2}{|c|}{ WONIEN } & \multirow{2}{*}{$\begin{array}{l}\text { SugGested NUtRiENT } \\
\text { DEFICIENCY } \dagger\end{array}$} \\
\hline & No. & $\%$ & No. & $\%$ & \\
\hline \multicolumn{6}{|l|}{ EYES } \\
\hline Blepharitis & 2 & 1 & 1. & 1 & Vitamin A, riboflavin \\
\hline Inflammation of eonjunctiva & 2 & 1 & 0 & 0 & No specific nutrient \\
\hline $\begin{array}{l}\text { Increased vascularity of conjunctiva } \\
\text { SKIN-FACE }\end{array}$ & 29 & 14 & 6 & 5 & No specific nutrient \\
\hline Nasalabial seborrhea & \multirow{2}{*}{$\begin{array}{r}17 \\
8\end{array}$} & \multirow{2}{*}{$\begin{array}{l}8 \\
4\end{array}$} & \multirow{2}{*}{$\begin{array}{l}2 \\
4\end{array}$} & \multirow{2}{*}{$\begin{array}{l}2 \\
4\end{array}$} & \multirow{2}{*}{$\begin{array}{l}\text { Riboflavin } \\
\text { Vitamin A, riboflavin }\end{array}$} \\
\hline $\begin{array}{l}\text { Aene } \\
\text { Mouth }\end{array}$ & & & & & \\
\hline Cheilosis & \multirow{6}{*}{$\begin{array}{r}8 \\
34 \\
0 \\
2 \\
0 \\
2\end{array}$} & \multirow{6}{*}{$\begin{array}{r}4 \\
16 \\
0 \\
1 \\
0 \\
1\end{array}$} & \multirow{6}{*}{$\begin{array}{l}2 \\
6 \\
1 \\
5 \\
1 \\
2\end{array}$} & \multirow{6}{*}{$\begin{array}{l}2 \\
5 \\
1 \\
4 \\
1 \\
2\end{array}$} & \multirow{6}{*}{$\begin{array}{l}\text { Riboflavin, niacin, iron } \\
\text { Vitamin C } \\
\text { Ribof., niacin, protein } \\
\text { Riboflavin, niacin } \\
\text { Niacin, ribofiavin } \\
\text { Niacin }\end{array}$} \\
\hline Gingivitis & & & & & \\
\hline Tongue, reddened …............... & & & & & \\
\hline Changes in tongue papillae .......... & & & & & \\
\hline Swelling of tongue & & & & & \\
\hline $\begin{array}{c}\text { Fissuring of tongue } \\
\text { THХROID GLAND }\end{array}$ & & & & & \\
\hline Enlargement & \multirow[t]{2}{*}{4} & \multirow[t]{2}{*}{2} & \multirow[t]{2}{*}{12} & \multirow[t]{2}{*}{10} & \multirow[t]{2}{*}{ Iodine } \\
\hline NeUrological Response & & & & & \\
\hline Changes in ................. & \multirow[t]{2}{*}{4} & \multirow[t]{2}{*}{2} & \multirow[t]{2}{*}{2} & \multirow[t]{2}{*}{2} & \multirow[t]{2}{*}{ Thiamine } \\
\hline SKIN & & & & & \\
\hline $\begin{array}{l}\text { Xerosis } \\
\text { Follieulosis }\end{array}$ & $\begin{array}{l}2 \\
4\end{array}$ & $\begin{array}{l}1 \\
2\end{array}$ & $\begin{array}{l}0 \\
0\end{array}$ & $\begin{array}{l}0 \\
0\end{array}$ & $\begin{array}{ll}\text { Vitamin } & \text { A } \\
\text { Vitamin } & \text { A }\end{array}$ \\
\hline
\end{tabular}

*Total number of men examined-210. Total number of women examined-125.

$\dagger$ Jolliffee, N., Tisdall, F.. and Cannon, P. (Editors), Clinical Nutrition, New York, Paul B. Hoeber Inc. 1950. Cayer David "Recognition and Treatment of Early Vitamin Deficiency States," Jour. Amer. Med. Assoc., Vol. 132, No. 10, p. 558, 1946.

were seen in 12 women and 4 men. Changes in neurological response were found in 2 per cent of the students examined.

Table 1 indicates that increased vascularity of the conjunctiva, inflamed eyelids, oily plugs in the skin, red peeling lips, inflamed gums, and rough, dry, goose-pimply or scaly skin were seen more frequently in the men than in the women students. Changes in the tongue and enlargements of the thyroid gland were found more often in the women. The fact that more nutritional defects possibly related to nutrition were seen in the male group may indicate that the higher food requirements of the men were not always met adequately. 


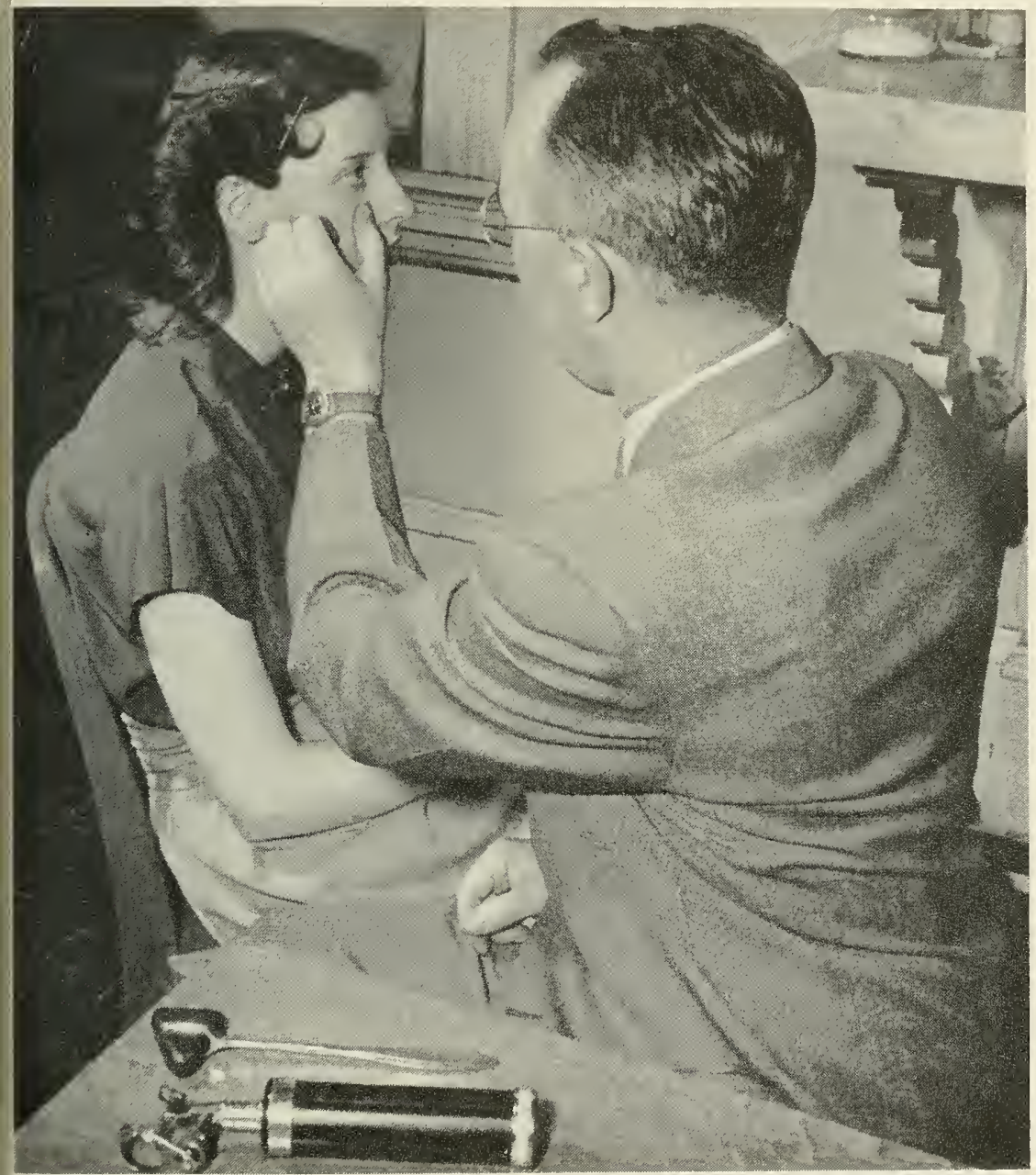

FIGURE 1. A PHYSICIAN examining a student for eye abnormalities.

\section{Microchemical Blood Studies}

Blood samples were obtained from each student cooperating in this survey at the end of the week in which the seven-day diet record was kept. These samples were taken by means of a finger puncture. Since inicrochemical analysis was used, only a few drops of blood were necessary for determinations of hemoglobin, vitamin $A$, carotene, and ascorbic acid content. A summary of the results of these blood tests is given in Chart 1. Each student was rated as "poor," "fair," "good," or "excellent" 
CHART I RESULTS OF BLOOD TESTS ON WEST VIRGINIA UNIVERSITY STUDENTS
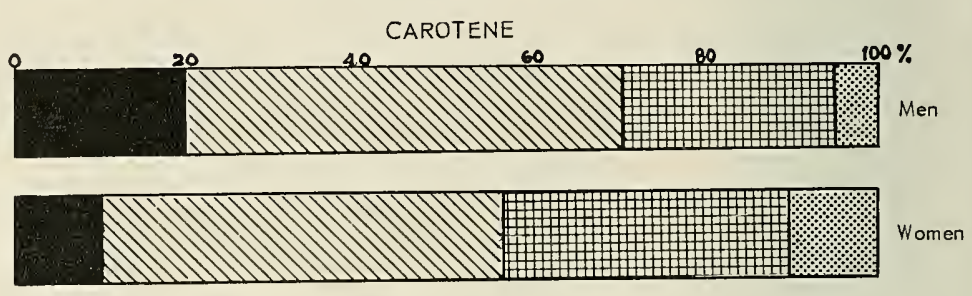

VITAMIN A
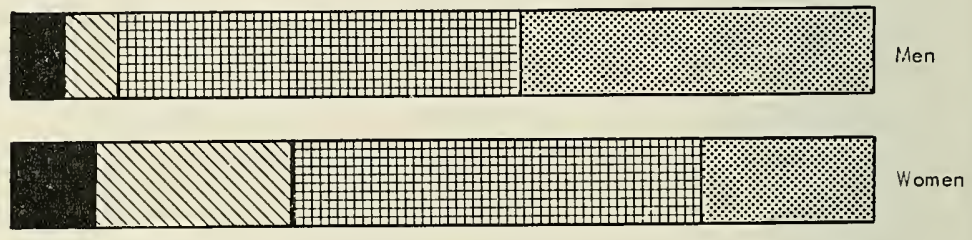

VITAMINI C
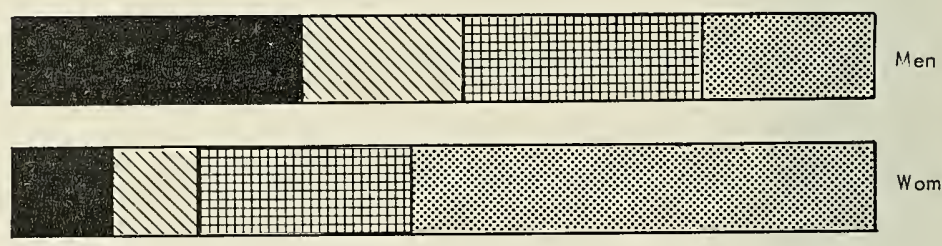

HEMOGLOBIN
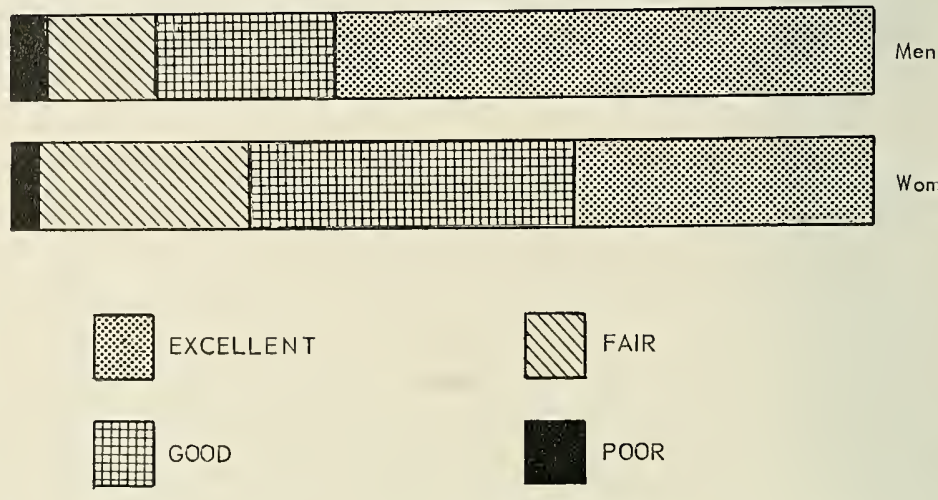
TABLE 2. Key to Interpretation of Blood Levels in Terms of AdEquAGY OF Nutrition*

\begin{tabular}{|c|c|c|c|c|}
\hline \multirow{2}{*}{ Nutritive Substance in Blood } & \multicolumn{4}{|c|}{ INDICATED LEVEL OF NUTRITION } \\
\hline & Poont† & FAIR & GOOD & EXCELLENT \\
\hline Vitamin A (ug. per $100 \mathrm{ml}$ ) & 19 & $20-29$ & $30-49$ & 50 \\
\hline 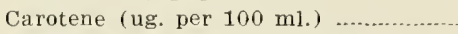 & 74 & $75-124$ & $125-199$ & 200 \\
\hline Ascorbic acid (mgs. per $100 \mathrm{ml}$ ) & 0.3 & $0.4-0.6$ & $0.7-1.0$ & 1.0 \\
\hline Hemoglobin (gms. per $100 \mathrm{ml}$.) .. & & & & \\
\hline Females, all ages ............. & 10.9 & $11.0-12.9$ & $13.0-13.9$ & 14.0 \\
\hline Viales, below $13 \ldots$. & 10.9 & $11.0-12.9$ & $13.0-13.9$ & 14.0 \\
\hline Males, 13 and 14 . & 11.4 & $11.5-13.4$ & $13.5-14.4$ & 14.5 \\
\hline Males, above $14 \ldots$ & 11.9 & 12.0-13.9 & $14.0-14.9$ & 15.0 \\
\hline
\end{tabular}

*Bessey, O. A., and Lowry, O. H., Nutritional Assay of 1,200 New York State School children; Meals for Millions, Final Report of the New York State Joint Legislative Comm. on Nutrition, 167-192, 1947.

$\uparrow$ These figures represent the lower end of the range for this group.

$\div \div$ These figures represent the highest end of the range for this group.

ranked "poor." About 50 per cent of all students rated only "fair" in this nutrient.

The results for ascorbic acid (vitamin C) show that more women than men were in the "good" and "excellent" groups. For example,

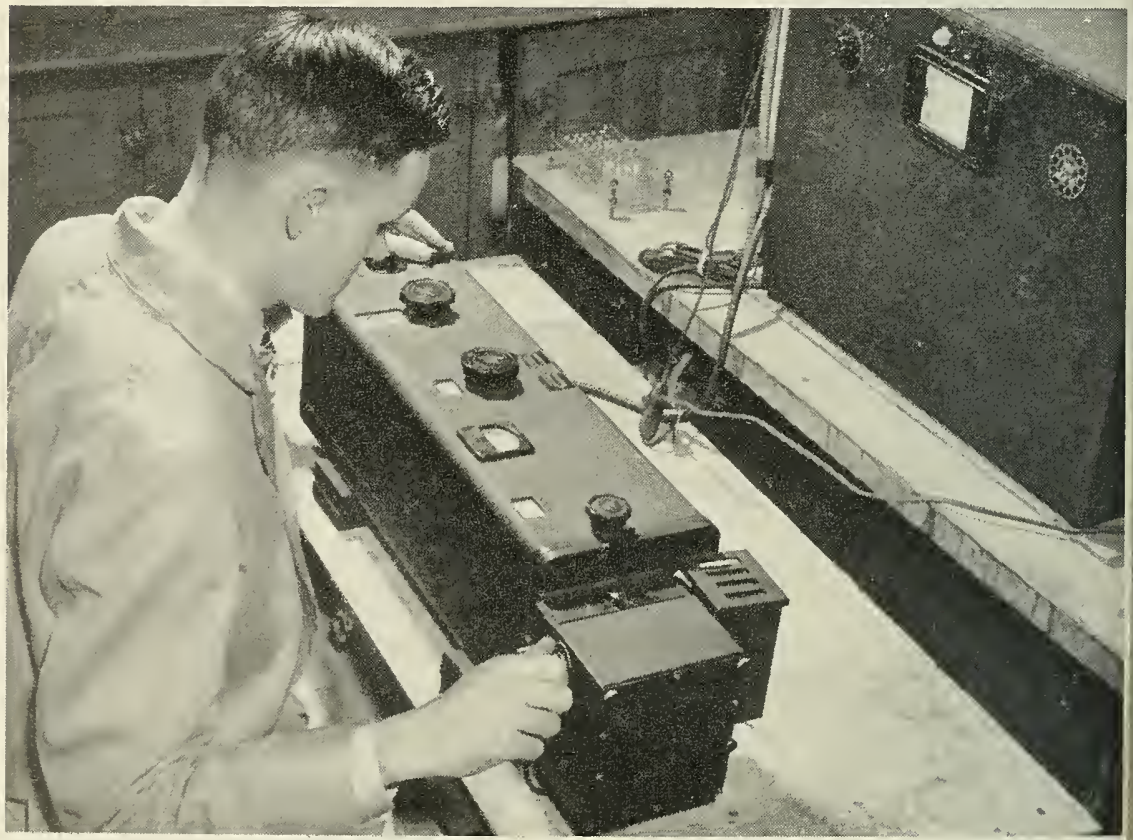

FIGURE 3. ANALYZING blood samples in the laboratory. 
about 40 per cent of the men were in the "poor" group, but only 11 per cent of the women were in this same group.

When classified according to the percentage of hemoglobin in the blood, almost 64 per cent of the men were rated "excellent." Only 36 per cent of the women ranked in this high group. About 24 per cent of the women and 12 per cent of the men rated only "fair" in hemoglobin. Less than 5 per cent of both men and women, however, were in the "poor" group.

The results of these blood tests have been broken down further in Chart 2 to show the ratings of both freshmen and upperclassmen for each of the four nutrients. The freshmen ratings are based upon blood samples collected immediately after the students enrolled in college and thus should reflect home dietary habits. Since the samples obtained from the upperclassmen were taken later in the school year, these values are considered indicative of school dietary patterns.

In most cases there is little difference in the ratings of the two groups. With carotene, for example, about 30 per cent of the freshmen and upperclassmen males rated "good," whereas approximately 5 per cent of both groups rated "excellent." The greatest difference in the carotene levels for the women occurred in the "fair" group, where there was a 10 per cent difference between freshmen and upperclassmen. In the case of vitamin $\mathrm{A}$, differences between ratings for both men and women students never exceeded 10 per cent.

For the men there was little difference between freshmen and upperclassmen in vitamin $\mathrm{C}$ and hemoglobin ratings. Freshmen women, however, rated lower than upperclasswomen for both of these nutrients. Forty-seven and 27 per cent of the freshmen rated "excellent" in vitamin $\mathrm{C}$ and hemoglobin respectively. In comparison, 61 and 43 per cent of the upperclasswomen rated "excellent" in these two nutrients.

From these data it seems that the diets of the male students at West Virginia University were similar to those that were eaten at home. On the other hand, it is suspected that women students ate more foods rich in vitamin $\mathrm{C}$ and iron at school than they did at home.

\section{Dietary Studies}

The data concerning food habits and dietary intake herein reported have been obtained from seven-day diet records kept by 535 students, 261 men and 274 women. Of these students, 155 men and 190 women were eating most of their meals at fraternity and sorority houses, and the remaining 106 men and 84 women were eating at dormitories, private homes, or restaurants. 


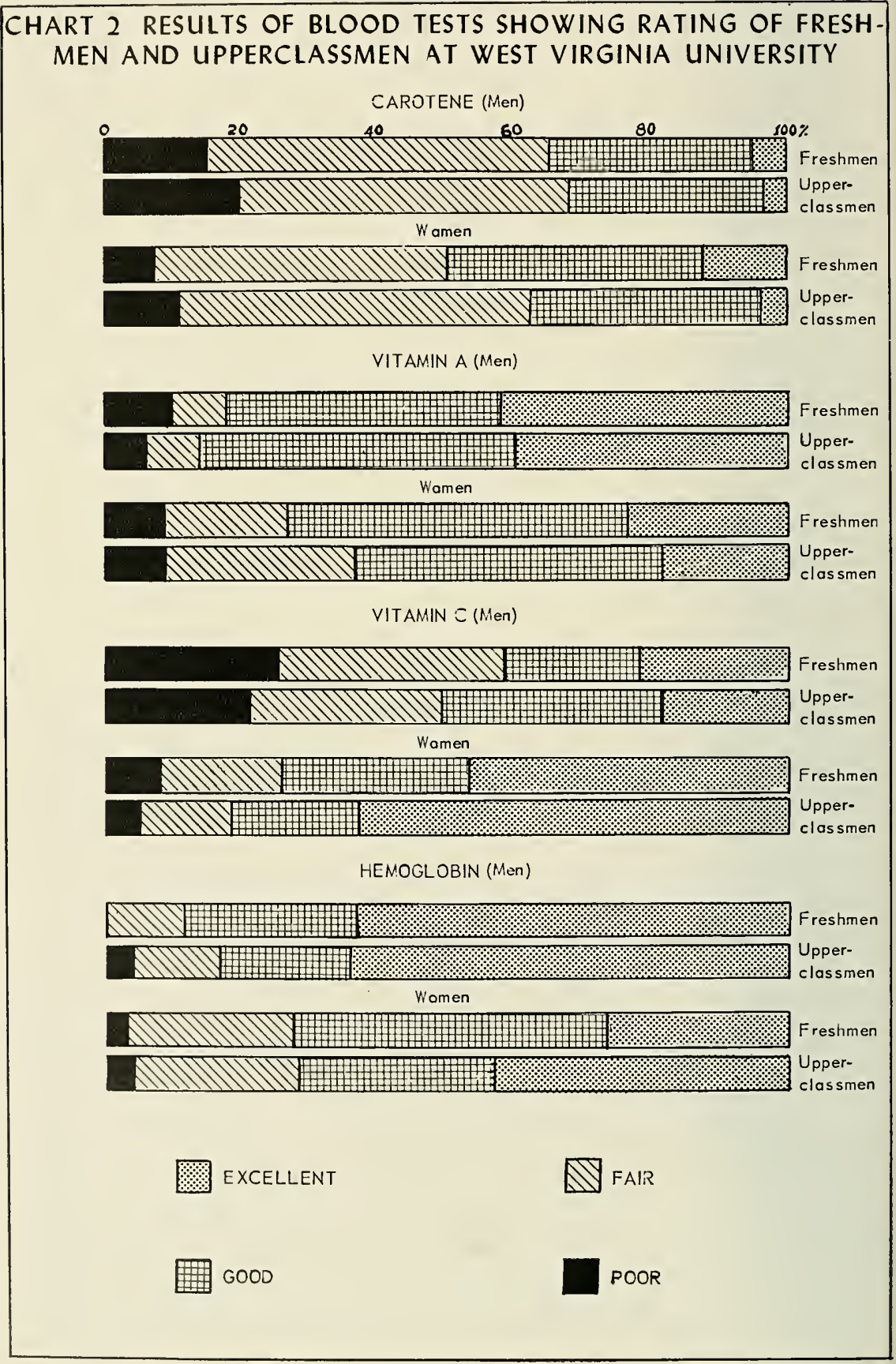


Each student was given a small booklet in which he or she was asked to record everything eaten over a period of one week. They were asked to record as accurately as possible the amounts eaten of each food and the manner in which it was prepared.

At the end of the seven-day period the diet record was returned to the nutritionist who checked it with the student for accuracy and completeness. Each subject's average daily intake of calories, protein, calcium, phosphorus, iron, vitamin A, thiamine, riboflavin, niacin, and ascorbic acid was then calculated by referring to standard tables of food composition. ${ }^{2}$

A summary of the results of these calculations is given in Chart 3 in terms of the Recommended Daily Dietary Allowances set up by the Foods and Nutrition Committee of the National Research Council. ${ }^{3}$ The National Research Council is composed of outstanding American scien tists representing about 85 national and scientific societies. Table 3 shows the actual amounts of the ten nutrients that have been recommended by this committee for a physically active man and a moderately active woman. These are the amounts believed to be necessary for safeguarding health and permitting proper maintenance of a normal, healthy body. Each allowance has been set up to include a wide "margin of safety," since individuals differ in their abilities to utilize the vitamins and minerals present in foods. With the exception of calories, daily intakes much greater than the recommendations can be tolerated by the human body without ill effects. Thus overconsumption of nutrients other than calories is not ordinarily considered a nutritional problem.

Chart 3 shows the proportion of students whose diets met or exceeded the NRC Daily Recommended Allowances for the ten mutrients studied and the proportion of students with dietary intakes below these recommended levels. Since many students had diets that failed to meet NRC standards for one or more of the nutrients, this latter group has been broken down further to show the percentage of students whose diets were less than 66.6 and 50 per cent of these levels.

Eighty per cent of the women were getting fewer than the recommended number of calories. Almost 17 per cent of these women had diets that furnished less than two-thirds of the calories recommended by the National Research Council, whereas 5 per cent were consmming foods that furnished less than one-half of this allowance. Thus it is not surprising that 31 per cent of the women students included in this

2Boyd, E. French, Eads, Mariam G., and Sanstead, Harold R., Food Value Tables for Calculation of diet records. U.S. Pub. Health Ser., Fen. Sec. Agen., 1947.

3National Research Council Reprint and Circular Series No. 129: Recommended Dietary Allowances; National Rescarch Council, Washington, D. C., Oct. 1948. 
CHART 3 PERCENTAGE OF WEST VIRGINIA UNIVERSITY STUDENTS WITH DIETARY INTAKES AT SELECTED LEVELS

CALORIES

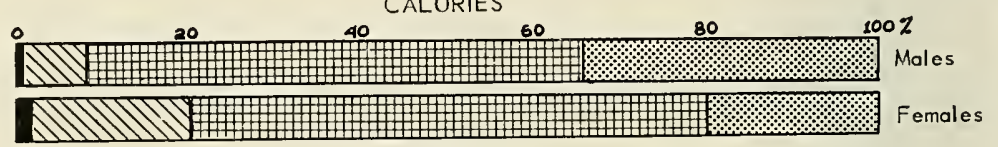

PROTEIN
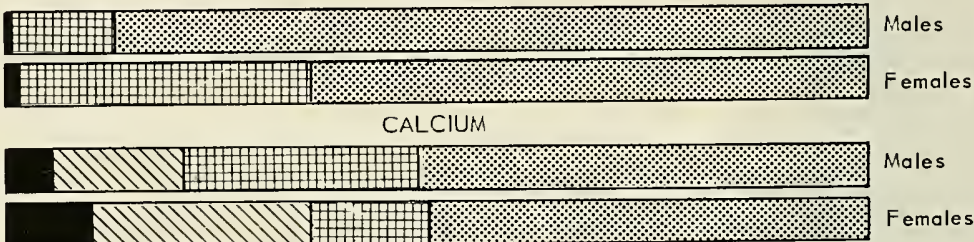

Males

Females

PHOSPHORUS

N1Y.

TIIIIIIIIIIII

Males

Females

IRON

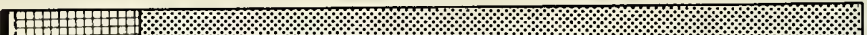

Males

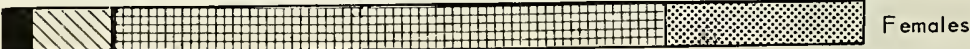

VITAMIN A

NIV W

Males

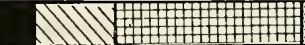

THIAMINE

NY\# \#

NWV

RIBOFLAVIN

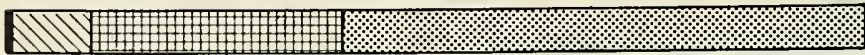

Males

TMV \# \#

NIACIN

NID

Males

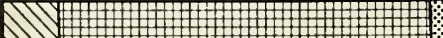

F emales

VITAMIN C

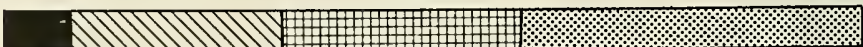

Males

MIIIIIII \#

Females

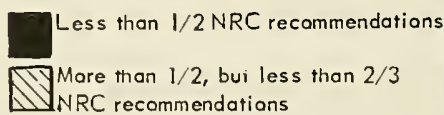

Mare than $2 / 3$, but less than tull
NRC recammendations
Meets or exceeds NRC recommendations 
TABLE 3. National REsearch Counchl's ReCommendil, Dally Dietary Allowances for a Puysically Active Man and a Modfrately

ACTive WOMAN*

\begin{tabular}{|c|c|c|}
\hline \multirow{2}{*}{ Nutrients } & \multicolumn{2}{|c|}{ Daily Dietary allowances } \\
\hline & MaN (154 LBS.) & WOMAN (123 LBS.) \\
\hline Calories, number & 3,000 & 2,400 \\
\hline Proteins, grams & 70 & 60 \\
\hline Calcium, grams & 1.0 & 1.0 \\
\hline Phosphorus, grams & 1.5 & 1.5 \\
\hline 1ron, milligrams & 12 & 12 \\
\hline Vitamin A, International Units $\ldots \ldots \ldots$ & 5,000 & 5,000 \\
\hline Thiamine, milligrams & 1.5 & 1.2 \\
\hline Riboflavin, milligrams & 1.8 & 1.5 \\
\hline Niacin, milligrams & 15 & 12 \\
\hline Vitamin C, milligrams & 75 & 70 \\
\hline
\end{tabular}

* National Research Council Reprint and Circular Series No. 129: Recommended Dietary Allowances; National Research Council, Washington, D. C., Oct. 1948.

nutritional survey were underweight, and only 6 per cent were overweight. Conversely, 30 per cent of the men students examined were found to be overweight. Only 12 per cent were underweight. Students considered over or underweight were those whose weights deviated 10 per cent or more from normal. Since 67 per cent of the men keeping diet records were getting less than the National Research Council Recommended Daily Allowance, it might be assumed that this allowance of 3,00 ? calories for a physically active man is a little high for college students. Only 8 per cent of the men were consuming diets that furnished less than two-thirds of the recommended number of calories, and only 2 per cent reported diets that furnished less than 1,500 calories a day.

Seventy-eight per cent of the men and 64 per cent of the women were consuming diets that met or exceeded the National Research Council's allowance for protein. Only three men and six women were getting less than two-thirds of the recommended levels. Since protein is necessary for building and repairing muscles, glands, blood, and other tissues, this high intake is encouraging.

Average daily intakes of calcium and phosphorus, minerals important in building and maintaining strong bones and teeth, were, in many cases, much lower than those recommended by the NRC. Almost 60 per cent of the students were getting less than the recommended amount of calcium, and 67 per cent were consuming less than the recommended amount of phosphorus. Eight per cent of the students had diets containing less than one-half of the daily allowance for calcium, and 18 per cent were consuming less than two-thirds of the NRC allowance for phosphorus. 


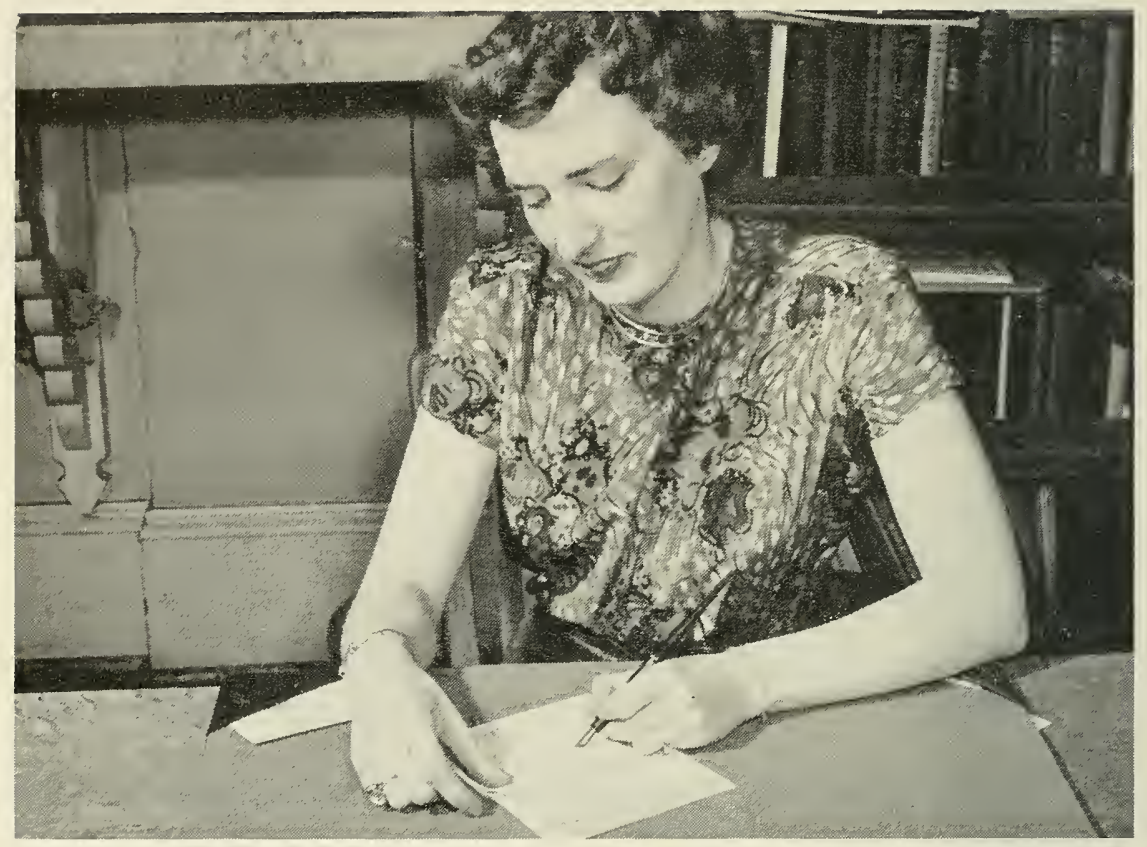

FIGURE 4. MAKING entries in a seven-day diet record book.

It is interesting to note that 79 per cent of the mens' diets met or exceeded the recommended intake of iron. On the other hand, only 20 per cent of the womens' diets met this level. Sixteen per cent of the women were getting less than two-thirds of the recommended amounts of this mineral which is a part of all red blood cells.

Trenty-nine per cent of the men and 37 per cent of the women had average daily intakes of vitamin A below the 5,000 International Units recommended by the NRC. Twelve men and seven women had daily intakes below two-thirds of this standard. Four men and 20 women were getting less than one-half of the recommended amount of vitamin A each day. Since vitamin A can be stored in the body, low intakes of this vitamin over short periods of time are usually compensated for by drawing upon body reserves. However, if a person continues to eat foods low in vitamin $A$, his reserve supply will soon be lowered. Vitamin $A$ is essential to the tissues that cover and line the body and helps them to resist infection. Thus persons habitually eating diets low in this vitamin may be more susceptible to infections of the skin and mucous membrane than those consuming foods high in vitamin $\mathrm{A}$.

Thiamine, riboflavin, and niacin, which are members of the $\mathrm{B}$ vitamin complex, all take specific parts in the processes by which foods 
are used in the body. Persons eating loods rich in these vitamins usually have more energy and vitality than those with diets low in the B-complex. Only 39 per cent of the men and 36 per cent of the women were consuming diets that met or exceeded the recommended allowances for thiamine. On the other hand, about 70 per cent of the mens' diets and 54 per cent of the womens' diets met or exceeded the recommended levels for riboflavin and niacin. Six per cent of the students had diets that supplied less than two-thirds of these allowances for thiamine, whereas 10 per cent were eating foods that furnished less than two-thirds of the recommended amounts of riboflavin. Diets of 4 per cent of the students were below this two-thirds level in niacin.

Although recent research indicates that our standards for vitamin $\mathrm{C}$ may be higher than necessary, the fact that 61 per cent of the men and 48 per cent of the women had intakes of vitamin $\mathrm{C}$ that were below $\mathrm{NRC}$ standards is noteworthy. This vitamin is essential to the health of the teeth, bones, blood vessels, and other tissues. Thus it is desirable that an adequate amount be included in the diet everyday. A daily intake of fifty milligrams is usually considered satisfactory lor adults. ${ }^{4}$ However, it is well to include a little more of this vitamin in the diet as a safeguard against abnormal conditions that might increase the body's need for vitamin C. Twenty-five per cent of the men and 23 per cent of the women were getting less than forty-five milligrams of vitamin $\mathrm{C}$ daily.

Percentage Contribution of Different Food Groups to the Nutritive QUALITY OF THE DIET

In order to get some information about home food consumption, a number of freshmen were asked to keep seven-clay diet records before they came to the University. These records were kept by $47 \mathrm{men}$ and 48 women during the week of September 7, 1949. After the average daily intake of each of the ten nutrients was calculated for each subject, a special study of these data was undertaken to determine the percentage contribution of certain common food groups to the total nutritive value ol each diet. The study was made by Mrs. Marion Brooks Connell.

The food groups selected lor this work were: breads, including all loods used as bread; milk, when used as a beverage; citrus fruits and tomatoes; eggs, when eaten as such; meat, fish, and poultry; white potatoes; and vegetables other than tomatoes and potatoes. Table I shows the relative contributions of each of these groups to the nutricive quality of each diet.

4Sherman, Henry C., Chemistry of foods and Nutrition, 7th ed., New York, MacMillan Company, 1946. 


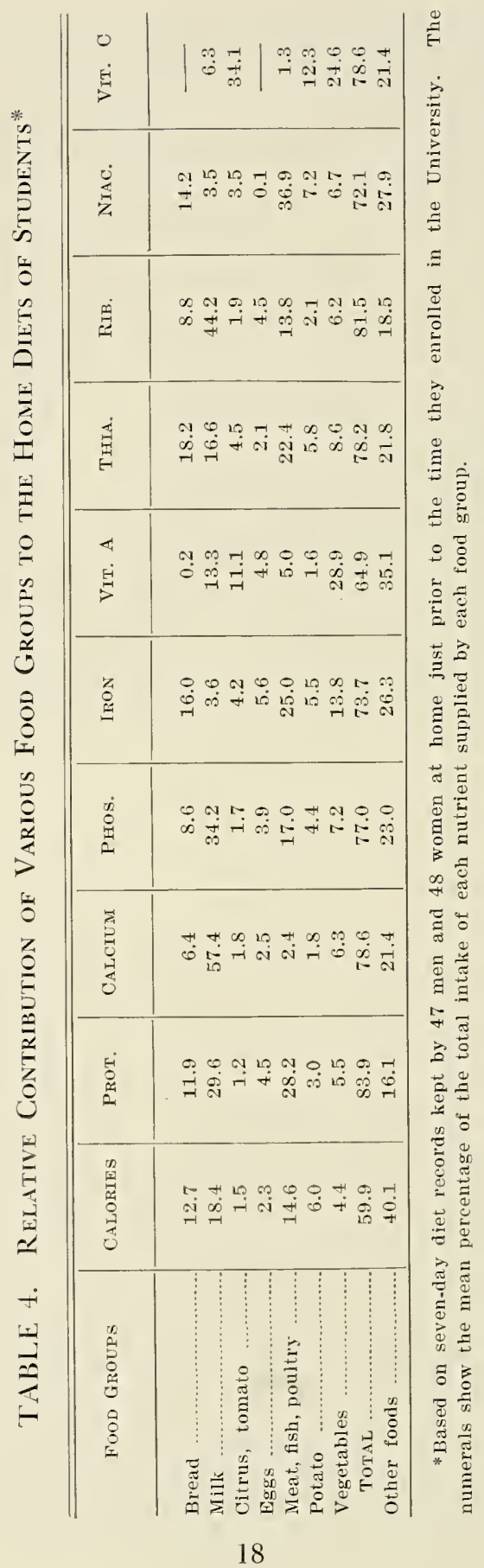


The percentages of each nutrient obtained from the different food groups were about the same for both men and women, even though the men ate much larger quantities of the foods studied. Milk furnished a higher percentage of calories, calcium, phosphorus, and riboflavin than any other single group of foods. The percentage of protein supplied by milk was only slightly more than that furnished by meat.

Bread was an important source of thiamine, riboflavin, and niacin for both men and women. Contrary to general belief, about the same proportion of calories was derived from bread by women as by men. White potatoes supplied only about 6 per cent of the total number of calories to both men and women.

Although potatoes were a fair source of vitamin C, about one-third of the total supply of this vitamin was obtained from citrus fruits and tomatoes.

Meat, fish, and poultry supplied a larger proportion of iron, thiamine, and niacin than any other food group. When this food group was broken down further, it was lound that the over-all contribution of fish was very small. Only eleven men and eighteen women ate fish during the seven-day period in which the diet records were kept.

Vegetables supplied over one-fourth of the total amounts of vitamin A in the diets. There was, however, little variety in the kinds of vegetables eaten over a seven-day period. Table 5 lists the types of vegetables eaten during the week by all of the subjects and the number of times each was reported. The average number of servings of vegetables per week was ten. Snap beans, corn, cabbage, peas, carrots, dried beans, lima beans, and lettuce were chosen most frequently. One must remember, however, that these diet records were kept during September when there are fewer fresh vegetables available than during the spring and summer months.

\section{General Discussion of Results}

It is encouraging to note that only a small percentage of the 335 students examined by a physician showed signs of those physical conditions that may be evidence of poor nutrition. One should remember. however, that dietary deficiencies may exist for long periods before any physical signs of mutritional deficiencies appent. Poor dicts may first be reflected in lowered concentrations of the various mutrients in the blood. Then if these deficient diets are continued for long periods of time, the body reserves are gradually depleted to make up lor the deficit in intake. When the reserves steadily fail to meet this deficit, a nutritional deficiency will develop. As this deficiency becomes more pro- 
Table 5. Vegetables Eaten During One Week by 95 Freshmen a WEST ViRgiNia UNIVERSITY*

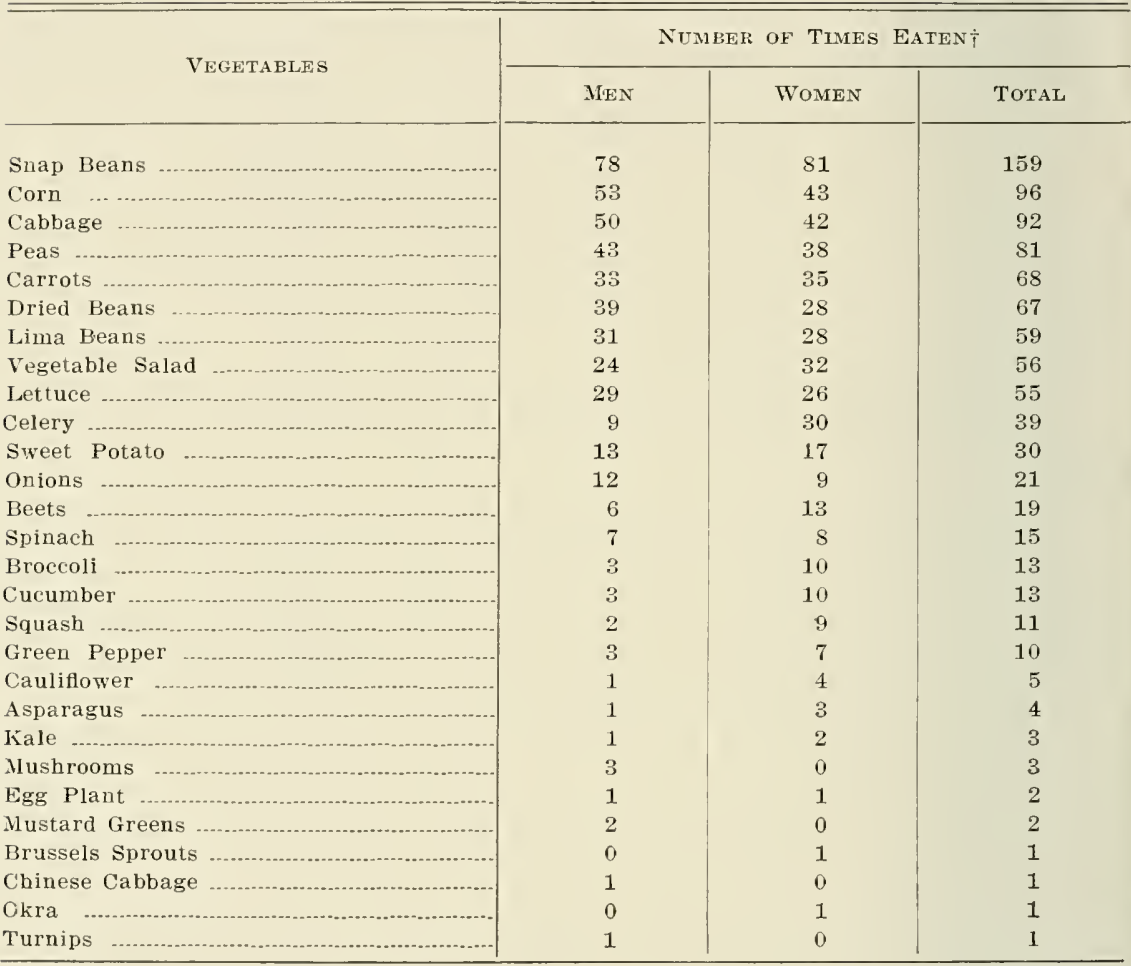

*Forty-seven men, 48 women.

$\uparrow$ Average number of servings per person per week-10.

nounced, the body functions may become slightly impaired. It is at this point that slight physical signs of nutritional deficiencies begin to appear. If the faulty diet is not corrected, these physical symptoms will gradually become more pronounced. Eventually an obvious deficiency disease may develop.

From the data furnished by the blood analysis, one might conclude that the students at West Virginia University need to include more green and yellow regetables in their diets to raise the level of carotene in their blood to the "good" or "excellent" range. Since most of the vitamin A in the body is obtained from carotene, these low levels might eventually affect the amount of vitamin $A$ present in the blood. The women in particular should eat more foods rich in carotene and vitamin $A$, for only 20 per cent of those studied rated "excellent" for vitamin A. All 
of the students, the men in particular, needed more citrus fruits, raw cabbage, or tomatoes to increase the vitamin $\mathrm{C}$ concentration in their blood. Since 24 per cent of the women were in the "fair" group for hemoglobin concentration, it is likely that more foods rich in iron would benefit this group.

In considering the dietary studies, it should be remenbered that vitamin deficiencies, when they do exist, usually occur as multiple deficiencies. A person may have a low intake of not only one, but several vitamins at the same time. This is especially true of the B-compley vitamins, thiamine, riboflavin, and niacin. A study of Chart 3 will indicate that there is still room for improvement in the diets of college students at this University. Many of the 535 students included in this study were consuming less than the National Research Council Recommended Daily Dictary Allowances. It is interesting to note that a greater percentage of the men met or exceeded the NRG standards for each nutrient except vitamin $\mathrm{C}$ than did the women. Small changes in food consumption could bring all of these diets up to the levels recommended by the National Research Council.

For example, inadequate intakes of calcium, phosphorus, and riboflavin could be corrected by increasing the daily intake of milk to one quart. Deficiencies in iron could be avoided by eating one serving of lean meat each day. This meat also would take care of the protein, thiamine, and niacin requirements. An occasional serving of liver would not only markedly increase iron intake, but also would furnish large amounts of vitamin $\mathrm{A}$ and the vitamin B-complex. Green leafy vegetables and dried fruits also might be good sources of iron.

Vitamin $A$ in the diet could casily be obtained from sweet potatoes, pumpkin, squash, carrots, or green, leafy vegetables. Tomatoes in all forms are good sources of vitamin A and C. Citrus fruits and juices and raw cabbage also are rich in vitamin $C$. Thiamine and niacin requirements may be met by increased use of whole grain products, unts, and peanut butter. About four eggs a reek should be included in the diet to supply additional anounts of protein, iron, and vitamin $\mathrm{A}$. 


\section{ot}

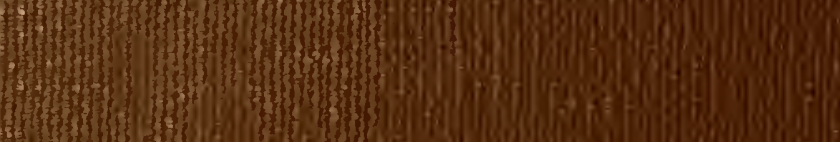

(3)

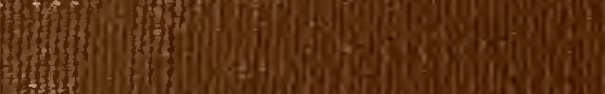

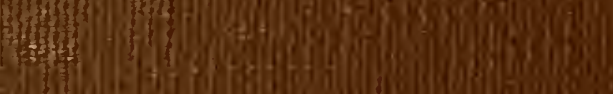

(3)

年:

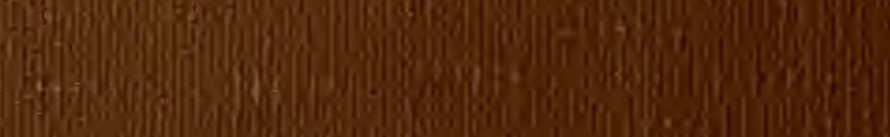

(1)

6)

ing

i)

ail

(1)

(6)

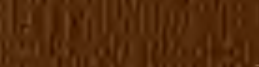

110

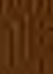

